\title{
PENINGKATAN KEMAMPUAN MENULIS DESKRIPSI DENGAN MENGGUNAKAN METODE FIELD TRIP PADA SISWA SEKOLAH DASAR
}

\author{
*Hj. Sri Ratnawati, M.Pd. \\ *e-mail: hjsriratnawati@gmail.com
}

\begin{abstract}
ABSTRAK
Penelitian ini bertujuan untuk meningkatkan kualitas proses dan hasil penulisan deskripsi siswa kelas V SDN Unggulan Kuningan , Kecamatan Kramatmulya, Kabupaten Kuningan dengan menerapkan metode pembelajaran field trip. Penelitian ini merupakan penelitian tindakan kelas. Subjek penelitiannya adalah 15 siswa kelas V SDN Unggulan Kuningan . Sumber data yang digunakan adalah tempat, informan, dan dokumen. Teknik pengumpulan data yang digunakan adalah observasi, wawancara, dan analisis dokumen. Validitas data dilakukan dengan menggunakan triangulasi sumber data dan triangulasi metode. Analisis data yang digunakan adalah teknik analisis interaktif. Penelitian ini dilakukan dalam dua siklus, masing-masing terdiri atas perencanaan, pelaksanaan, observasi, dan refleksi. Hasil penelitian menunjukkan bahwa penerapan metode field trip dalam pembelajaran menulis deskriptif dapat meningkatkan minat belajar siswa dari $53 \%$ pada siklus I menjadi $73 \%$ pada siklus II. Selain itu, keaktifan siswa selama pembelajaran juga meningkat menjadi 53\% pada siklus I menjadi $87 \%$ pada siklus II. Prestasi belajar siswa juga meningkat dari sebelumnya, yaitu $60 \%$ siswa mencapai KKM dengan nilai rata-rata 65,8 pada siklus I meningkat menjadi $87 \%$ siswa mencapai KKM dengan nilai rata-rata 75,25. Simpulan penelitian ini adalah penerapan metode field trip dalam pembelajaran menulis deskripsi dapat meningkatkan kualitas proses dan prestasi belajar siswa kelas V dari SDN Unggulan Kuningan. Hal ini dapat ditunjukkan oleh peningkatan ketertarikan siswa, keaktifan siswa, dan prestasi belajar siswa dari siklus I ke siklus II.
\end{abstract}

Kata kunci: menulis deksripsi, metode field trip, minat menulis, kemampuan menulis.

\section{PENDAHULUAN}

Pembelajaran bahasa di sekolah menitikberatkan pada empat keterampilan berbahasa. Keterampilan tersebut menurut Henry Guntur Tarigan meliputi keterampilan menyimak, berbicara, membaca dan menulis (1993: 1). Keempat keterampilan ini saling berhubungan dan saling menunjang satu sama lain. Hal itu dikarenakan keempat aspek tersebut sangat penting, pembelajaran bahasa dimasukkan dalam kurikulum mata pelajaran Bahasa Indonesia.

Seperti yang tercantum dalam Kurikulum Tingkat Satuan Pendidikan yang disusun oleh Pusat Kurikulum Badan Penelitian dan Pengembangan Departemen Pendidikan Nasional (2006: 9), disebutkan bahwa salah satu tujuan mata pelajaran Bahasa Indonesia adalah siswa dapat berkomunikasi secara efektif dan efisien sesuai dengan etika yang berlaku, baik secara lisan maupun tertulis. Dari pernyataan tersebut tersirat bahwa keterampilan menulis cukup mendapatkan perhatian dalam pendidikan dan pembelajaran terutama di sekolah. 
Menulis merupakan kemampuan yang paling akhir dikuasai setelah peserta didik mampu menyimak, berbicara, dan membaca. Hal tersebut tidak mengherankan karena dalam menulis, peserta didik diharuskan untuk menguasai berbagai unsur kebahasaan dan unsur di luar bahasa itu sendiri sehingga tulisan yang dihasilkan dapat runtut dan padu, kohesif, dan kohern. Oleh karena itu, pembelajaran menulis ini harus diajarkan, dibina dan dikembangkan secara intensif di semua jenjang pendidikan. Saat ini, pembelajaran menulis yang diadakan di sekolah-sekolah belum maksimal. Sebagai contoh dalam penelitian ini, pada kegiatan observasi awal dan pratindakan yang dilakukan pada siswa kelas V SDN Unggulan Kuningan diketahui bahwa nilai hasil pembelajaran menulis deskripsi masih rendah atau belum memenuhi KKM, begitu pula proses pembelajarannya. Proses pembelajaran menulis deskripsi yang dilakukan guru masih menggunakan metode konvensional.

Menurut guru yang mengampu kelas tersebut hal tersebut di sebabkan oleh beberapa faktor, diantaranya: (1) kurang antusiasnya siswa dalam mengikuti pelajaran menulis deskripsi; (2) siswa mengalami kesulitan dalam memahami materi menulis deskripsi; (3) siswa merasa jenuh atau bosan pada mata pelajaran bahasa Indonesia yang selama ini dilakukan secara monoton; (4) guru kesulitan membangkitkan keaktifan siswa; (5) guru belum menggunakan metode pembelajaran yang inovatif; (6) kurangnya pembimbingan guru saat siswa mengerjakan tugas menulis deskripsi; dan (7) guru kesulitan dalam menemukan dan menerapkan metode pembelajaran yang tepat dalam mengajar materi menulis deskripsi.

Permasalahan utama yang dialami siswa dalam menulis deskripsi selama ini adalah tidak dimunculkannya objek pengamatan secara langsung, hal itu membuat siswa kebingungan dalam mendeskripsikan objek yang diamati sehingga hasil belajarnya masih rendah. Permasalahan pembelajaran menulis deskripsi di SDN Unggulan Kuningan ini dapat diatasi dengan penggunaan metode pembelajaran yang tepat agar dapat memperbaiki dan meningkatkan keterampilan siswa. Salah satu metode yang dapat digunakan untuk mengatasi masalah ini adalah dengan menggunakan metode field trip. Pada pembelajaran menggunakan metode field trip ini siswa diajak untuk melihat objek pengamatan secara langsung. Metode ini membuat siswa lebih jelas, cermat, dan rinci dalam mendeskripsikan objek sehingga hasil deskripsinya menjadi lebih akurat dan sesuai dengan kenyataan yang mereka lihat.

Kaitannya dengan metode pembelajaran field trip, Semiawan, dkk menjelaskan metode karyawisata (field trip) ialah suatu cara menyajikan bahan pelajaran dengan membawa siswa langsung kepada obyek yang akan dipelajari yang terdapat di luar kelas. (1985: 79). Pada kegiatan pembelajaran menggunakan metode ini, siswa diajak berkunjung ke lingkungan sekitar untuk membuat karangan deskripsi. Jadi, siswa tidak hanya sekadar belajar teori-teori tentang menulis, tetapi juga diharapkan menghasilkan sebuah produk, berupa karangan deskripsi. Adapun tujuan teknik ini adalah dengan melaksanakan field trip diharapkan siswa dapat memperoleh pengalaman langsung dari objek yang dilihatnya, dapat turut menghayati tugas pekerjaan milik seseorang serta dapat bertanggung jawab. Mungkin dengan jalan demikian mereka mampu memecahkan persoalan yang dihadapi dalam pembelajaran (Roestiyah. 2001: 85).

Dengan belajar dengan cara melihat objek secara langsung seperti yang dikemukakan di atas maka hal ini akan sangat membantu siswa dalam menutis karangan deskripsi dimana dalam karangan deskripsi, penulis dituntut untuk menggambarkan objek serinci mungin. Sebagaimana yang diungkapkan Keraf (1981: 93) bahwa tulisan deskripsi merupakan sebuah 
bentuk tulisan yang bertahan dengan usaha para penulis untuk memberikan perincianperincian dan objek yang sedang dibicarakan.

Dalam beberapa penelitian yang telah dilakukan sebelumnya, Dwi Setyaningsih (2010) dalam tesisnya yang berjudul Penerapan Metode Field Trip untuk Meningkatkan Kemampuan Menulis Puisi pada Siswa Kelas V SDN Lengkong Kecil Bandung Tahun Ajaran 2009/2010. Pada penelitiannya, Dwi Setyaningsih menerapkan metode field trip dengan cara membagi siswa dalam beberapa kelompok, masing-masing kelompok melakukan pengamatan terhadap objek tertentu misal pohon, bangku, dan sebagainya.

Setelah melakukan pengamatan, siswa kembali ke kelas untuk menyusun puisinya sebelum akhirnya dikumpulkan kepada guru. Hasil penelitiannya yaitu :

(1) keaktifan dan kesungguhan siswa selama pembelajaran meningkat dari siklus I ke siklus II yakni dari 65,38\% menjadi 88,46\%; (2) kemampuan siswa dalam mengidentifikasi rincian topik yang akan ditulis dalam puisi naik dari 84,6\% menjadi 96,2\%; (3) kemampuan siswa dalam mengolah kata menjadi baris-baris puisi naik dari $53,8 \%$ menjadi $86,5 \%$; dan (4) kemampuan siswa dalam menulis puisi naik dari $50 \%$ menjadi $84,6 \%$. Dari penelitian tersebut dapat ditarik simpul bahwa penerapan metode field trip dapat meningkatkan kualitas proses dan hasil dalam pembelajaranan menulis puisi pada siswa V SDN Unggulan Kuningan.

\section{METODE}

Penelitian ini dilakukan pada siswa kelas V SDN Unggulan Kuningan , Kecamatan Kramatmulya, Kabupaten Kuningan . Waktu pelaksanaan penelitian ini dimulai pada bulan Januari hingga bulan Juni 2017. Subjek penelitian dalam penelitian ini adalah 15 siswa kelas V SDN Unggulan Kuningan, kecamatan Kramatmulya. Guru yang dijadikan mitra dalam penelitian ini adalah Ibu Enok Elin Septiani, M.Pd. beliau merupakan guru kelas serta wali kelas V. Penelitian ini merupakan penelitian tindakan kelas. Sumber data yang dipergunakan berupa sumber data peristiwa, informan dan dokumen. Teknik pengumpulan data sesuai dengan sumber datanya yakni observasi, wawancara, dan analisis dokumen. Uji validitas data menggunakan teknik triangulasi sumber data dan triangulasi metode. Analisis data yang dipergunakan adalah teknik analisis interaktif. Penelitian dilaksanakan dalam dua siklus, dengan tiap siklus terdiri atas kegiatan perencanaan, pelaksanaan tindakan, observasi, dan refleksi.

\section{HASIL PENELITIAN}

Kegiatan pratindakan merupakan kegiatan yang dilakukan sebelum peneliti melakukan penelitian di tempat yang telah ditentukan. Pada penelitian ini, peneliti melakukan kegiatan pratindakan dengan dua cara yakni dengan tes tertulis oleh siswa, dan juga wawancara terhadap guru dan beberapa orang siswa. Kegiatan pratindakan melalui tes tertulis menulis deskripsi dilaksanakan pada hari Senin, 27 Februari 2017 terhadap 15 orang siswa. Pada kegiatan pratindakan ini, metode yang digunakan adalah metode yang biasa digunakan guru dalam mengajar, begitupun dengan RPP nya.

Dari kegiatan tersebut diketahui hal-hal sebagai berikut. Pertama dilihat dari aspek proses pembelajarannya. Pada proses pembelajaran menulis deskripsi berlangsung, guru 
memberikan materi dengan metode ceramah seperti biasanya, kemudian guru memberi contoh dan langsung memberikan tugas menulis kepada siswa dengan topik yang telah disiapkan. Selama siswa mengerjakan tugas menulis deskripsi, guru tidak melakukan banyak aktivitas, guru lebih banyak duduk di mejanya sambil terkadang mengerjakan administrasi sekolah. Pada kegiatan ini juga diketahui bahwa guru lebih mendominasi kegiatan pembelajaran dibandingkan siswa. Guru jarang sekali mengkonfirmasi pemahaman siswa secara mendalam. Pada saat mengerjakan tugas menulis guru tidak melakukan bimbingan intensif kepada siswa, hal ini menyebabkan guru tidak tahu sejauh mana kemampuan siswa yang sebenarnya. Ketika siswa kesulitan saat mengerjakan, kebanyakan siswa merasa enggan dan takut bertanya kepada guru, mereka lebih nyaman untuk bertanya kepada temantemannya, padahal di sini seharusnya guru lah yang berperan penting untuk memecahkan permasalahan yang dihadapi siswa dalam belajar dengan terus berada di ruang kelas dan memantau pekerjaan siswa serta membantu mereka saat mereka kesulitan dengan tugas yang diberikan.

Dari segi keaktifan siswa selama proses pembelajaran terlihat siswa kurang aktif karena lebih banyak mendengarkan penjelasan guru. Siswa yang bertanya saat pembelajaran pun hanya 4 orang siswa. Hal ini berarti dari segi keaktifan hanya $27 \%$ siswa yang aktif dari keseluruhan 15 orang siswa. Dari aspek hasil belajar siswa pada kegiatan pratindakan, juga terlihat bahwa hasil pekerjaan menulis karangan deskripsi oleh siswa belum memuaskan. Dari 15 siswa yang ada, siswa yang nilainya sudah memenuhi KKM hanya sebanyak 3 siswa atau baru $20 \%$ saja, dengan rata-rata nilai 51,67. Persentase dan nilai rata-rata ini tentunya masih tergolong sangat rendah dan perlu adanya resolusi atau terobosan baru dalam pembelajaran yang dilaksanakan guru sehingga hasil belajar siswa dapat ditingkatkan semaksimal mungkin.

Berdasarkan pada survei awal yang dilakukan pada kegiatan pratindakan, diketahui bahwa ada tiga permasalahan utama yang menyebabkan nilai siswa tidak mencapai batas minimal ketuntasan belajar yakni proses pembelajaran yang dilakukan guru masih bersifat konvensional, kemampuan menulis siswa yang masih rendah dan siswa kurang berpartisipasi pada saat pembelajaran berlangsung. Sebagai alternatifnya, peneliti bersama guru menggunakan metode pembelajaran field trip untuk memecahkan masalah tersebut. Berdasarkan kesepakatan siklus I dilakukan dalam 2 kali pertemuan yakni pada tanggal 12 dan 13 Maret 2017. Tiap satu pertemuan berlangsung selama 2 jam pelajaran dengan kalkulasi waktu 70 menit.

Selama pelaksanaan tindakan, guru bertindak sebagai pemimpin jalannya kegiatan belajar mengajar, sedangkan peneliti bertindak sebagai kolaborator yang membantu pelaksanaan pengajaran yang dilakukan guru dan sebagai pengamat jalannya kegiatan pembelajaran. Pada kegiatan pelaksanaan tindakan ini guru menggunakan bahasa campuran antara bahasa Indonesia dan bahasa Jawa agar siswa dapat lebih mudah memahami materi yang diajarkan. Selain itu, bahasa campuran ini digunakan agar penekanan-penekanan materi dalam kegiatan pembelajaran lebih mengena di benak dan pikiran siswa.

Adapun prosedur tindakan yang dilakukan pada pelaksanaan siklus I adalah: (1) guru memasuki ruang kelas, meminta ketua kelas untuk memimpin doa sebelum pelajaran dimulai, melakukan absensi, dan menanyakan apakah siswa sudah siap untuk belajar atau belum; (2) selanjutnya guru melakukan apersepsi dengan teknik tanya jawab; (3) pada kegiatan 
eksplorasi, guru bertanya jawab mengenai materi menulis karangan untuk mengetahu pemahaman siswa; (4) guru menyimpulkan pendapat siswa dan memberi penjelasan lebih lengkap; (5) guru memberi contoh bagaimana cara mendeskripsikan suatu objek; (6) memasuki kegiatan elaborasi siswa diminta guru untuk berlatih mendeskripsikan sebuah tas sekolah milik salah satu siswa; (7) siswa mulai menulis tentang tas itu, guru memantau mereka dari meja guru sambil mengerjakan dokumen yang lain; (8) setelah beberapa menit guru meminta siswa membacakan hasil deskripsiny; (9) siswa diajak untuk berkeliling sekolah dimulai dari pintu gerbang hingga halaman belakang; (10) siswa mencatat apa yang mereka lihat dalam buku masing-masing; (11) siswa diminta menulis karangan deskripsi berdasarkan hasil pengamatan mereka; (12) guru meminta siswa membacakan karyanya di depan kelas; (13) guru melakukan konfirmasi dan memberikan penguatan terhadap hasil karya siswa; (14) guru menyimpulkan pembelajaran menulis deskripsi hari itu, dan melakukan refleksi; dan (15) guru member tahu rencana pembelajaran bahasa Indonesia pada pertemuan berikutnya dan kemudian menutup pelajaran.

Kegiatan observasi (pengamatan) dilakukan oleh peneliti pada saat proses pembelajaran sedang berlangsung, posisi peneliti berada di belakang kelas sehingga siswa tidak terganggu dengan kehadiran peneliti. Yang menjadi perhatian dalam kegiatan observasi adalah aspek sikap baik guru maupun siswanya. Dari kedua pelaksanaan pembelajaran di atas dapat disimpulkan bahwa dalam siklus pertama ini ditemukan hal-hal sebagai berikut. Pertama, pada pertemuan pertama pembelajaran berlangsung cukup baik namun pada pertemuan guru dan siswa kurang disiplin. Kedua, guru sudah melaksanakan sebagian prosedur meskipun belum lengkap. Ketiga, guru belum sepenuhnya melakukan pembimbingan kepada siswa. Keempat, guru belum memberikan umpan balik kepada siswa tentang seberapa jauh tingkat pemulihan siswa setelah materi disampaikan. Kelima, masih ada siswa yang malu-malu atau takut ketika akan menjawab pertanyaan guru. Keenam, guru masih kurang memberikan motivasi lagi kepada siswa untuk lebih percaya diri pada saat pembelajaran. Ketujuh, pada pertemuan kedua guru belum melakukan refleksi terhadap hasil belajar siswa walaupun hanya sekilas. Kedelapan, siswa belum paham sepenuhnya mengenai materi menulis deskripsi, terlihat saat guru keluar kelas banyak siswa yang bertanya kepada temannya. Kesembilan, pada pembelajaran pertemuan kedua, guru kurang memperhatikan waktu mengajar.

Dari hasil penerapan metode field trip pada siklus tersebut diperoleh hasil sebagai berikut. Pertama, dari segi minat siswa. Minat ini dilihat dari seberapa banyak siswa yang dapat memfokuskan perhatiannya pada saat pembelajaran, baik pada saat guru menerangkan, melakukan pengamatan, maupun saat menyusun karangan. Dari aspek ini diketahui bahwa, siswa yang memiliki minat tinggi saat mengikuti pelajaran sudah cukup banyak yakni 8 siswa atau sekitar 53\%. Kemudian dari segi keaktifan siswa dapat dilihat dari seberapa banyak siswa yang aktif bertanya, menjawab pertanyaan, dan dengan suka rela mau membacakan hasil tulisannya di depan kelas. Dari segi keaktifan diketahui bahwa siswa yang sudah aktif sebanyak 8 siswa atau $53 \%$.

Aspek yang terakhir yakni hasil belajar siswa. Hasil belajar siswa ini dapat dilihat setelah guru bersama peneliti melakukan penilaian terhadap hasil pekerjaan siswa. Dari hasil penilaian diketahui bahwa siswa yang nilainya sudah mencapai KKM sebanyak 9 siswa atau $60 \%$ dengan nilai rata-rata 65,8 . Nilai rata-rata siswa belum termasuk kategori memuaskan bahkan masih sedikit dibawah KKM. Dari hasil analisis pekerjaan siswa diketahui bahwa 
sebagian siswa yang nilainya belum memenuhi KKM mengalami kesulitan dalam pembentukan kalimat yang baik dan efektif, oleh karena itu perlu adanya penambahan materi pada siklus berikutnya. Dari hasil kegiatan observasi dan analisis dapat diperoleh refleksi sebagai berikut. Pertama, guru hendaknya dapat mengkondisikan siswa dengan baik selama pembelajaran berlangsung dari awal hingga akhir pembelajaran. Kedua, guru harus memberikan penjelasan, pengarahan dan motivasi kepada siswa agar siswa bisa paham benar mengenai materi dan lebih disiplin serta bertanggung jawab dalam mengerjakan tugas. Ketiga, guru harus lebih optimal dalam menggunakan metode field trip dan dalam melakukan bimbingan terhadap siswa. Keempat, guru memberikan kesempatan siswa untuk lebih aktif dalam kegiatan pembelajaran. Kelima, guru lebih memperhatikan alokasi waktu saat melakukan pembelajaran.

Kegiatan perencanaan bahwa siklus II dilaksanakan pada tanggal 27-28 Maret 2017. Pada kegiatan ini seperti pada siklus sebelumnya yakni menentukan waktu pembelajaran, membuat Rencana Pelaksanaan Pembelajaran, mementukan objek pengamatan, dan menyiapkan segala hal yang menunjang pembelajaran menulis deskripsi dengan metode field trip.

Pada tahap pelaksanaan, guru lebih berusaha untuk melakukan apa yang sudah ada dalam Rencana Pelaksanaan Pembelajaran. Adapun prosedur tindakan yang dilakukan pada pelaksanaan siklus I adalah : (1) guru mengkondisikan siswa untuk mengikuti pelajaran bahasa indonesia; (2) guru mulai melakukan apersepsi dengan menanyakan kembali kepada siswa tentang materi menulis deskripsi; (3) guru bertanya jawab dengan siswa mengenai penyusunan kalimat yang baik; (4) guru menerangkan materi tentang struktur kalimat yang baik dan kemudian mengaplikasikan kalimat yang baik tersebut untuk menulis deskripsi serta memberi contoh paragraf deskripsi yang baik; (5) siswa diminta untuk berlatih mendeskripsikan kelas mereka sendiri dalam 2-3 kalimat dengan objek yang telah dibagi-bagi oleh guru. misal meja dan kursi di kelas $\mathrm{v}$, meja guru di kelas $\mathrm{v}$, luas ruangan kelas $\mathrm{v}$, dan seterusnya; (6) siswa yang sudah selesai diminta untuk menulisnya di papan tulis dan langsung dikoreksi guru bersama siswa yang lain; (7) guru menjelaskan kegiatan yang akan dilaksanakan dengan metode field trip; (8) siswa diajak untuk melakukan pengamatan di sebuah mesjid yang letaknya tidak jauh dari sekolah; (9) siswa mencatat hasil pengamatan mereka dalam bukunya masing-masing; (10) siswa diajak kembali ke kelas dan diminta untuk membuat karangan deskripsi berdasarkan hasil pengamatan; (11) guru secara intensif membimbing siswa selama pembelajaran berlangsung; (12) guru menawarkan kepada siswa yang ingin membacakan karangannya di depan kelas; (13) guru mengkonfirmasi kembali pemahaman siswa mengenai karangan deskripsi, guru memberikan applause dan pujian bagi semua siswa sebagai penguatan karena mereka telah bekerja keras untuk membuat karangan deskripsi yang baik; (14) guru menyimpulkan kegiatan pembelajaran dan melakukan refleksi, serta mengumpulkan lembar jawab siswa; dan (15) guru menutup pelajaran.

Kegiatan observasi pada siklus kedua ini pelaksanaannya sama dengan pada siklus pertama yakni melakukan pengamatan pada saat pembelajaranberlangsung. Dari hasil pengamatan peneliti baik siswa maupun guru melaksanakan kegiatan belajar dan pembelajaran dengan lebih baik dibanding pada siklus pertama. Guru sudah terlihat konsisten dalam pengajarannya dengan rencana pembelajaran yang telah dibuat bersama peneliti. Mulai 
dari pertemuan pertama, guru membuka pelajaran dengan cara yang sudah baik. Siswa juga lebih siap menerima pelajaran dibanding sebelumnya. Pada kegiatan apersepsi siswa yang aktif ketika siswa diajak diskusi oleh guru dengan cara bertanya jawab ada 9 siswa yang aktif. Pada kegiatan ini juga terlihat bahwa guru aktif memberikan motivasi kepada siswa agar tidak takut bertanya maupun menjawab pertanyaan. Langkah memotivasi siswa yang dilakukan guru ini sangat membantu dalam upaya peningkatan keaktifan siswa dalam pembelajaran karena dapat meningkatkan rasa percaya diri siswa di kelas, di depan guru dan teman-temannya. Pada pertemuan kedua ini guru juga dapat mengatur pembelajaran dengan baik sesuai dengan alokasi yang disediakan.

Dari kedua pelaksanaan pembelajaran diatas dapat disimpulkan bahwa dalam siklus II ini ada beberapa hal yang pelaksanaannya belum optimal, diantaranya; (1) guru belum menyeluruh memberikan dorongan kepada siswa untuk aktif di dalam kelas selama pembelajaran; (2) masih ada siswa yang masih takut untuk bertanya kepada guru; (3) guru perlu melakukan kontrol kelas lebih baik lagi terutama untuk siswa laki-laki yang sering bercanda dan mengganggu temannya saat pembelajaran berlangsung; dan (4) guru hendaknya menegur atau memberi sanksi bila memang diperlukan untuk siswa yang masih sulit dikendalikan.

Penerapan metode field trip pada siklus kedua ini diperoleh hasil sebagai berikut. Yang pertama dari segi minat siswa yang dilihat dari pengamatan saat pelajaran berlangsung. Minat ini dilihat dari seberapa banyak siswa yang dapat memfokuskan perhatiannya pada saat pembelajaran, baik pada saat melakukan pengamatan, maupun saat menyusun karangan.

Dari aspek ini diketahui bahwa, siswa yang memiliki minat tinggi saat mengikuti pelajaran sudah cukup banyak yakni 11 siswa atau sekitar 73\%. Kemudian dari segi keaktifan juga diamati pada saat pembelajaran di kelas sedang berlangsung. Keaktifan siswa dapat dilihat dari seberapa banyak siswa yang aktif bertanya, menjawab pertanyaan, dan dengan suka rela mau membacakan hasil tulisannya di depan kelas. Dari segi keaktifan diketahui bahwa siswa yang sudah aktif sebanyak 13 siswa atau 87\%. Aspek yang terakhir yakni hasil belajar siswa. Hasil belajar siswa ini dapat dilihat setelah guru bersama peneliti melakukan penilaian terhadap hasil pekerjaan siswa. Dari hasil penilaian diketahui bahwa siswa yang nilainya sudah mencapai KKM sebanyak 13 siswa atau 87\% dengan nilai rata-rata 75,25. Nilai rata-rata siswa ini sudah mengalami peningkatan dari siklus sebelumnya. Dari hasil analisis pekerjaan siswa diketahui bahwa sebagian siswa yang nilainya belum memenuhi KKM belum sepenuhnya mengerti tentang mendeskripsikan objek dengan kalimat yang baik, namun dia ragu-ragu untuk bertanya kepada guru.

Dari hasil kegiatan observasi dan analisis di atas maka dapat diperoleh refleksi sebagai berikut: (1) Guru hendaknya dapat mengontrol siswa terutama siswa putra yang sering membuat suasana kelas menjadi agak gaduh dalam pembelajaran, mungkin dengan diberi teguran, memindah tempat duduk mereka, atau memberi sanksi yang tegas. (2) Guru seharusnya memberikan bimbingan kepada siswa lebih menyeluruh dan intens selama pembelajaran. (3) Guru memberikan kesempatan lebih bagi siswa yang masih belum aktif di dalam kelas. (4) Guru harus lebih memberikan motivasi secara kontinyu sehingga rasa percaya diri siswa dapat ditingkatkan. 


\section{Perbandingan Hasil Penelitian}

Pelaksanaan pratindakan, siklus I dan siklus II menunjukkan adanya peningkatan baik dari aspek minat siswa terhadap pelajaran, tingkat keaktifan siswa, dan nilai hasil belajar siswa. Berikut penjelasan dari ketiga aspek tersebut.

Minat siswa terhadap pelajaran menulis deskripsi. Seperti yang telah dijelaskan sebelumnya, minat siswa dapat dilihat dari seberapa banyak siswa yang dapat memfokuskan perhatiannya pada saat pembelajaran, baik pada saat guru menerangkan, melakukan pengamatan, maupun saat menyusun karangan. Dari siklus pertama diketahui bahwa siswa yang minatnya tinggi selama pembelajaran berlangsung sebanyak 8 siswa atau sekitar 53\% dan pada siklus II siswa yang aktif naik menjadi 11 siswa atau $73 \%$.

Tingkat keaktifan siswa saat mengikuti pembelajaran menulis deskripsi. Dari segi keaktifan siswa, pengamatan dilakukan terhadap keaktifan siswa pada saat apersepsi, eksplorasi, elaborasi dan konfirmasi, baik keaktifan dalam bertanya maupun menjawab pertanyaan guru. Pada siklus I siswa yang aktif selama pembelajaran terhitung 8 orang siswa atau 53\% siswa. Hasil pengamatan pada siklus II menunjukkan bahwa keaktifan siswa meningkat menjadi 13 anak atau sekitar 87\%. Pencapaian pada siklus II ini keaktifan siswa sudah memenuhi target pencapaian indikator penelitian.

Hasil belajar siswa dalam menulis deskripsi. Hasil belajar siswa dinilai dari hasil pekerjaan menulis deskripi siswa. Tulisan deskripsi yang dibuat siswa dinilai berdasarkan kriteria tertentu. kriteria ini meliputi isi, organisasi, kosakata, pengembangan bahasa, dan mekanik penulisan. Dari hasil penilaian guru bersama peneliti pada siklus I diperoleh bahwa siswa yang nilainya sudah mencapai KKM baru 9 orang siswa atau $60 \%$ dengan nilai rata-rata 65,8. Sedangkan hasil pembelajaran pada siklus II membuahkan hasil yang cukup memuaskan, yakni siswa yang nilainya sudah mencapai KKM sebanyak 13 anak atau 87\% dengan nilai rata-rata 75,25 .

Perbandingan hasil pencapaian antarsiklus di atas dapat dilihat dalam grafik berikut

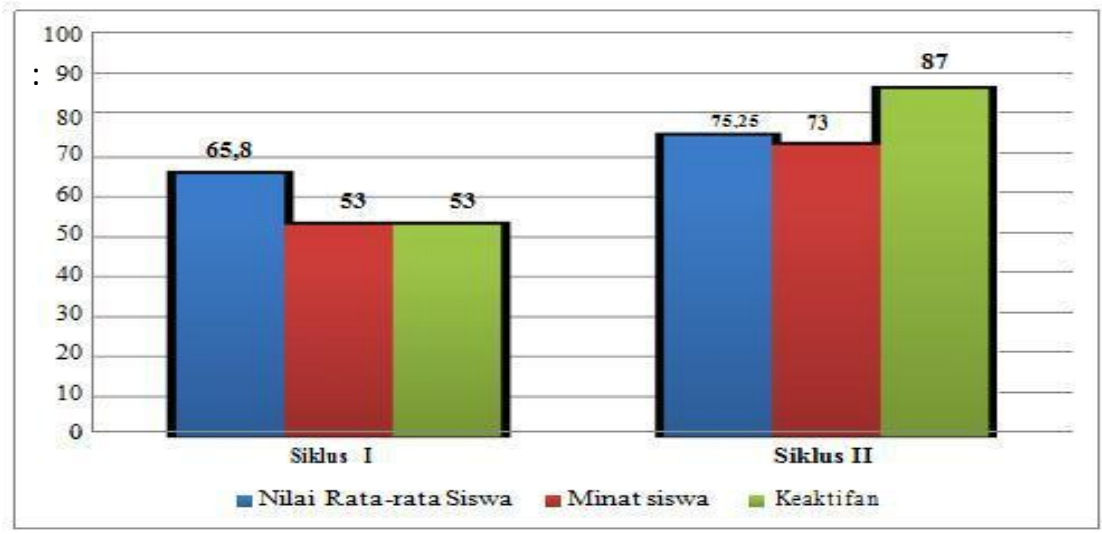

Gambar 1. Grafik Perbandingan Hasil Penelitian

\section{PEMBAHASAN}

Dalam keberhasilan penerapan metode field trip dalam upaya meningkatkan kemampuan menulis deskripsi dapat dilihat hal-hal berikut.

Siswa terlihat memiliki minat yang tinggi dalam mengikuti pelajaran menulis deskripsi. 
Sebelum tindakan penelitian ini dilaksanakan, siswa terlihat kurang berminat. Hal tersebut disebabkan siswa tidak tertarik dengan cara mengajar yang biasa digunakan guru. Cara yang biasa digunakan guru adalah ceramah dan penugasan saja. Kelemahan dari metode tersebut adalah munculnya suatu kebosanan dan keengganan pada siswa, sehingga menyebabkan siswa tidak tertarik mengikuti pelajaran dan minatnya juga rendah. Setelah penerapan metode field trip, suasana pembelajaran menjadi berbeda, siswa tampak senang dan memperhatikan pelajaran, siswa lebih fokus kepada materi dibandingkan berbicara dengan teman saat pembelajaran.

\section{Siswa terlihat aktif dalam mengikuti pelajaran menulis deskripsi}

Sebelum penerapan metode field trip banyak siswa yang hanya diam tanpa merespon stimulus yang diberikan guru selama pembelajaran, mereka berani menjawab pertanyaan jika menjawabnya bersama-sama satu kelas, siswa juga terkesan masih malu, ragu-ragu dan takut untuk menyampaikan pendapat,

menjawab pertanyaan guru maupun bertanya kepada guru. Ketika guru mulai menerapkan metode field trip, siswa mulai aktif bertanya maupun menjawab pertanyaan, selain itu mereka sudah terbiasa untuk mengacungkan jari sebelum menjawab pertanyaan dan juga menjawab pertanyaan guru secara individu. Kepercayaan diri siswa perlahan-lahan meningkat, hal tersebut mengindikasikan bahwa metode field trip cocok digunakan untuk pembelajaran menulis deskripsi.

\section{Siswa mengalami peningkatan nilai menulis deskripsi}

Sebelum ada penelitian hasil belajar menulis deskripsi siswa masih tergolong rendah. Siswa yang nilainya memenuhi KKM belum ada separuh kelas. Setelah pelaksanaan metode field trip dalam pembelajaran menulis deskripsi, terbukti bahwa nilai siswa meningkat dari pada sebelumnya. Jumlah siswa yang nilainya sudah mencapai KKM pun meningkat cukup banyak.

\section{Kinerja guru meningkat setelah mengajar menulis deskripsi dengan penerapan metode field trip.}

Sebelum menggunakan metode pembelajaran field trip, guru hanya mengajar dengan metode konvensional, belum memunculkan media pembelajaran yang inovatif, dan lain sebagainya. Namun dengan adanya penerapan metode ini guru menjadi lebih aktif, guru lebih memancarkan energi positif selama pembelajaran berlangsung guru lebih aktif membimbing siswa, hal seperti ini sangat disukai oleh siswa kelas V SDN Unggulan Kuningan . Guru yang memiliki kinerja tinggi seperti ini akan dapat membantu siswa dalam berprestasi. Siswa juga akan selalu menantikan untuk diajar guru yang memiliki kinerja yang tinggi.

Dalam teori yang di kemukakan oleh Roestiyah (2001: 85) bahwa field trip bukan sekedar rekreasi, tetapi untuk belajar atau memperdalam pelajaran dengan melihat kenyataan. Hal itu sesuai dengan pembelajaran yang dilakukan oleh guru yakni memperdalam pelajaran dengan melihat kenyataan, pada penelitian ini guru mengajak siswa melakukan pengamatan langsung objek sehingga apa yang mereka tulis benar-benar berdasarkan kenyataan yang mereka lihat. Menurut Semiawan, dkk (1985) metode karyawisata (field trip) ialah suatu cara menyajikan bahan pelajaran dengan membawa siswa langsung kepada obyek yang akan dipelajari yang terdapat di luar kelas. Hal tersebut sejalan dengan penelitian ini, dimana pelaksanaan field trip cukup dilaksanakan di sekitar lingkungan sekolah terhadap objek yang benar-benar nyata sebagai sumber belajarnya. 
Berdasarkan hasil penelitian di atas, diketahui bahwa ada banyak perubahan baik tingkah laku siswa maupun hasil pembelajarannya mulai dari siklus I hingga siklus II. Dari segi tingkah laku, siswa sudah dapat fokus dalam pembelajaran, dan sudah mulai membiasakan diri untuk aktif di kelas, selain itu dengan banyak latihan hasil menulis deskripsi siswa pun mengalami peningkatan. Hal ini sejalan dengan yang diungkapkan Hamalik (2003) yang menyatakan bahwa belajar adalah perubahan tingkah laku yang relatif mantap berkat latihan dan pengalaman. Perubahan menjadi lebih baik pada penelitian menulis deskripsi yang terjadi pada saat pembelajaran hanya dapat terencana saat guru dapat merencanakan kegiatan pembelajaran dengan baik dan menekankan pada pemahaman, keaktifan siswa, dan optimalisasi penggunaan sumber belajar.

\section{SIMPULAN DAN SARAN}

Dari penelitian menulis deskripsi yang dilakukan pada siswa kelas V SD N Unggulan Kuningan ini dapat disimpulkan: (1) penerapan metode field trip dapat meningkatkan kualitas proses pembelajaran menulis deskripsi pada siswa kelas V SDN Unggulan Kuningan ; (2) penerapan metode field trip dapat meningkatkan kualitas hasil pembelajaran menulis deskripsi pada siswa kelas V SDN Unggulan Kuningan .

Saran yang dapat penulis ajukan berkaitan dengan penelitian ini yaitu: (1) bagi guru, dengan penerapan metode field trip pada pembelajaran menulis deskripsi diharapkan guru dapat menerapkan metode pembelajaran tersebut seefektif mungkin dengan memperhatikan waktu yang tersedia; (2) bagi siswa, dalam pelaksanaan pembelajaran menulis deskripsi dengan menggunakan metode field trip, hendaknya siswa dapat memaksimalkan waktu yang ada untuk melakukan pengamatan dan menyusun karangan dengan baik; (3) bagi sekolah, sekolah hendaknya lebih memfasilitasi pelaksanaan pembelajaran menulis deskripsi dengan menyiapkan sarana dan prasarana yang memadai; (4) bagi peneliti yang lain, hendaknya dapat mempergunakan hasil penelitian ini dengan bijaksana sebagai bahan perbandingan terhadap penelitian yang akan dilakukan.

\section{DAFTAR PUSTAKA}

Akhadiah, S. (1996). Pembinaan Kemampuan Menulis Bahasa Indonesia. Jakarta: Erlangga.

Andayani. (2009). Pendekatan Pembelajaran Bahasa dan Sastra Indonesia. Salatiga: Widyasari.

Arikunto, S., dkk. (2007). Penelitian Tindakan Kelas. Jakarta: Bumi Aksara.

Depdiknas. (2006). KTSP: Standar Kompetensi Mata Pelajaran. Jakarta: Depdiknas.

Enco, M. (2003). Menjadi Guru Profesional. Bandung: Remaja Rosdakarya.

Gie, T.L. (2002). Pengantar Dunia Karang Mengarang. Yogyakarta: Andi.

Hamalik, O. (2003). Perencanaan Pengajaran Berdasarkan Pendekatan Sistem. Jakarta: Bumi Aksara. 
Iskandarwassid \& Sunendar, D. (2008). Strategi Pembelajaran Bahasa. Bandung: Remaja Rosdakarya.

Keraf, G. (1981). Eksposisi dan Deskripsi. Jakarta: Nusa Indah.

Roestiyah. dkk. (2001). Strategi Belajar Mengajar. Jakarta: Rineka Cipta.

Sagala, S. (2006). Konsep dan Makna Pembelajaran. Bandung: Alfabeta.

Sardiman, A.M.. (2000). Interaksi dan Motivasi Belajar Mengajar. Jakarta: Raja Grafindo Persada.

Semiawan, C. (1985). Pendekatan Keterampilan Proses. Jakarta: Gramedia.

Setyaningsih, D. (2010). Penerapan Metode Field Trip untuk Meningkatkan Kemampuan Menulis Puisi pada Siswa Kelas V SDN Lengkong Kecil Bandung Tahun Ajaran 2009/2010. Skripsi: UPI.

Tarigan, H.G. (1993). Menulis Sebagai Suatu Keterampilan Berbahasa. Bandung: Angkasa. 